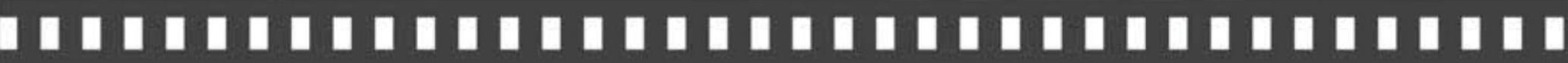

\author{
El gusto por los otros: turismo, fotografía y \\ patrimonio cultural en el contexto andino
}

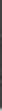

\author{
Juan Pablo Silva-Escobar \\ Valentina Raurich
}

Artigo recebido em: 09/07/2019

Artigo aprovado em: 03/11/2020 


\title{
El gusto por los otros: turismo, fotografía y patrimonio cultural en el contexto andino
}

\author{
The taste for others: tourism, photography and \\ cultural heritage in the andean context
}

Juan Pablo Silva-Escobar*

Valentina Raurich**

\begin{abstract}
Resumen: El objetivo de nuestro artículo es discutir y reflexionar acerca del patrimonio cultural, el turismo y la práctica fotográfica dentro del contexto cultural andino, especificamente Bolivia y Perú. Nos concentraremos en analizar cómo se han construido determinadas imágenes que se han vuelto representaciones hegemónicas de aquellos grupos sociales que se quiere retratar. Sostenemos que el turismo, el patrimonio cultural y la fotografia constituyen una triada que contribuye a la idealización de la alteridad, presentando a ciertas comunidades y su patrimonio cultural como atracciones imperdibles y como mundos exóticos plagados de una etnicidad convertida en fetiche.
\end{abstract}

Palabras clave: Globalización. Patrimonio cultural. Fotografia. Turismo

\begin{abstract}
The objective of our paper is to discuss and to think about the cultural heritage, tourism and photographic practice within the Andean cultural context, specifically, Bolivia and Peru. We will concentrate on analysing how certain images have been built and become hegemonic representations of those social groups that they want to portrait. We argue that tourism, cultural heritage and photography constitute a triad that contributes to the idealization of otherness, presenting their
\end{abstract}

* Doctor en Antropología, Universidad de Valladolid, España. Centro de Investigaciones en Artes y Humanidades (CIAH), Facultad de Artes, Universidad Mayor, Chile. Centro de Estudios Históricos (CEH), Universidad Bernardo O'Higgins.

** Investigadora independiente. 
174 El gusto por los otros: turismo, fotografía y patrimonio cultural en el contexto andino

cultural heritage as must-see attractions and exotic worlds littered with a fetishized ethnicity.

Keywords: Globalization. Cultural heritage. Photography. Tourism.

\section{Introducción}

El propósito de nuestro trabajo es discutir y reflexionar acerca del patrimonio cultural, el turismo y la práctica fotográfica dentro del contexto cultural andino, específicamente Bolivia y Perú. Nos concentraremos en analizar cómo se construyen determinadas imágenes que se vuelven hegemónicas sobre aquellos grupos sociales que se quieren representar. Planteamos que el turismo se ha posicionado como uno de los principales mediadores en la articulación y construcción de significados culturales, configurando todo un entramado sociocultural que deviene en una práctica que jerarquiza y legitima, simbólica, política y económicamente, determinados territorios y prácticas culturales. En tal sentido, la patrimonialización de ciertos espacios y manifestaciones suelen atender a elementos supuestamente idiosincrásicos que remiten a un pasado que se presume compartido por una cierta comunidad. Sin embargo, con la irrupción del turismo de masas, ciertos espacios sociales, las tradiciones y las subjetividades han sido progresivamente transmutados hacia una suerte de decorados perfectos para el consumo del turismo masivo. Nuestro objetivo es analizar el modo en que el turismo construye un mundo ideal e idealizado de una otredad que es objetivada como un bien de consumo, que presenta 
a ciertas comunidades y su patrimonio cultural como atracciones imperdibles, como mundos exóticos plagados de una etnicidad originaria y mística.

Sostenemos que el turismo, el patrimonio cultural y la práctica fotográfica que se desarrolla dentro del contexto andino, dejan entrever la confección de un conjunto de imaginarios que de la identidad, el patrimonio y la alteridad en un espectáculo destinado al consumo que, fabrica lo andino como diferencia fetichizada, que se estructura sobre la base de dos tipos de relaciones que se influyen mutuamente: "las de fuerza, correspondientes al valor de uso y de cambio, y, dentro de ellas, entretejidas con esas relaciones de fuerza, hay relaciones de sentido, que organizan la vida social, [a través de] relaciones de significación" (GARCÍA CANCLINI, 2005 , p. 34). Este entrelazamiento de fuerza y sentido, trae consigo la instalación un conjunto de imágenes y discursos que se hacen figurable como representaciones, que actúan sobre el campo social a través de prácticas socioculturales (turismo, el patrimonio $\mathrm{y}$ fotografía), e instituyen "formas étnicas nuevas y más altamente deterministas que las que se produjeron durante la primera fase colonial" (MACCANNELL, 2007, p. 165).

Nuestro análisis se sustenta en la teoría decolonial, es decir, utilizamos un marco epistemológico que teoriza la estructuración de la modernidad a partir de la noción de colonialidad. Este acercamiento teórico nos permite acceder a las problemáticas ligas a la fotografía, el turismo y el patrimonio que se desarrollan dentro del capitalismo avanzado desde "la noción de estructuras de dominación que atraviesan lo social y afectan lo político vinculándose al sistemamundo" (MORAÑA, 2014, p. 16). Desde esta perspectiva se 
entiende que la colonialidad del poder no es un estado de cosas que antecede a la modernidad, sino que es un aspecto constitutivo de los mismos procesos de modernización. Siguiendo los planteamientos de Aníbal Quijano (1992, 2007), planteamos que la colonialidad se articula como uno de los dispositivos centrales del patrón mundial del poder capitalista, que se origina y expande a partir de la conquista de América. Una colonialidad que se establece como "la imposición de una clasificación de corte racial/étnica de la población como piedra angular de dicho patrón de poder, que opera en cada uno de los planos, ámbitos y dimensiones, materiales y subjetivas de la existencia cotidiana y a escala social" (QUIJANO, 2007, p. 93).

Desde la conquista de América en adelante el capitalismo se hace mundial, estableciéndo lo que Immanuel Wallerstein (1989) ha denominado como el moderno sistema-mundo: una nueva configuración geopolítica, económica, social y cultural eurocentrada, donde la modernidad y la colonialidad se instalan como estructuras estructurantes de un proceso en constante acomodo y rearticulación. Esta ideología no se ejerce desde un único y soberano lugar, sino que se ejerce desde una multiplicidad de lugares que tienden a naturalizar y domesticar sujetos y subjetividades, "que emanan de abajo, de las entrañas del cuerpo social, procediendo de fuerzas locales, móviles y transitorias, a veces minúsculas, hasta organizarse en potentes homogeneidades que se convierten en hegemónicas" (BLANCHOT, 1993, p. 54). En consecuencia, la colonialidad no es algo que afecte sólo a ciertos países, sino que es un fenómeno que se desarrolla y desenvuelve a partir de una experiencia global compartida que atañe tanto a colonizadores como colonizados.

El colonialismo territorial y nacionalista de la modernidad ha 
dado paso a un colonialismo posmoderno y desterritorializado, donde el poder simbólico, el consumo y la globalización se articulan como piedras angulares para lograr diseminar un sistema de dominación, en el que se cristalizan los desequilibrios de poder que existen entre el centro y la periferia. "Dentro de esta estructura de poder, el primero asume una posición ideológica privilegiada, autoritaria y central, marginando al segundo a la periferia" (ECHTNER; PRASAD, 2003, p. 668).

El discurso contemporáneo, imbuido de ideologías coloniales, sigue legitimando y perpetuando la desigualdad (CHANG; HOLT, 1991). Se instaura, así, un sistema de dominación simbólico que va más allá y es tanto más efectivo que los tanques, los mísiles y los soldados, puesto que las palabras y las imágenes actúan sobre la imaginación de los dominadores y los dominados. El resultado es una visión consolidada que afirma no sólo el derecho de unos sobre otros a dominar sino también su obligación de hacerlo. Como ha observado Edward Said (2001, p. 44), tanto el colonialismo como el imperialismo se encuentran sostenidos por un conjunto de "formaciones ideológicas que incluyen la convicción de que ciertos territorios y pueblos necesitan y ruegan ser dominados".

\section{Indexicalidad de la imagen fotográfica}

Hans Belting (2010), sostiene que la imagen fotográfica suele ser entendida ya sea como un fragmento que la cámara arrancó al mundo visible, o bien como una técnica aplicada a la tecnología fotográfica de acuerdo a un determinado método. "En un caso la 
imagen es un rastro del mundo; en el otro una expresión del medio que la produce; la imagen fotográfica se ubica dentro de los parámetros que su método comprende, esto es, entre la toma de la fotografía y la producción de la copia" (BELTING, 2010, p. 263).

Esta toma de posición respecto de la fotografía es lo que lleva a Vilém Flusser (1990) a plantear que las imágenes se articulan como superficies significativas que tienen el potencial de hacernos imaginable el mundo y sus relaciones; en tal sentido las imágenes fotográficas no serían sólo contingencia pura, ni tampoco capturarían exclusivamente aquello que se encuentra en el mundo visible, sino como ha señalado Susan Sontag (2006), las representaciones que hacemos del mundo, las hacemos con representaciones de nuestra propia imaginería. De este modo, las imágenes fotográficas "[...] se interponen entre el hombre y el mundo; pretenden ser mapas, y se convierten en pantallas. En vez de presentar el mundo al hombre, lo re-presentan; se colocan en lugar del mundo a tal grado que el hombre vive en función de las imágenes que el mismo ha producido" (FLUSSER, 1990, p. 12).

Cuando Roland Barthes (1986), en su análisis de la fotografía periodística, afirma que la imagen fotográfica no es lo real, pero lo que la define es su perfección analógica $\mathrm{y}$, por tanto, es un mensaje sin código cuya significación es elaborada a partir de un contexto histórico particular. Por otra parte, la connotación, "es decir la imposición de un sentido secundario al mensaje fotográfico propiamente dicho" (BARTHES, 1986, p. 16), se elabora en el nivel de la composición, del estilo, de la impronta del fotógrafo y sus intenciones. Esta ausencia de código señalada por Barthes es discutible pues, como escribe Pierre Bourdieu (2003), la invención de 
la fotografía, lejos de establecer sus propios estándares de realismo, simplemente siguió los lineamientos de la ideología dominante que gobernaba la pintura:

Si la fotografía es considerada como un registro perfectamente realista y objetivo del mundo visible, es porque se le ha asignado (desde el origen) unos usos sociales considerados "realistas" y "objetivos". Y si se ha presentado inmediatamente con las apariencias de un "lenguaje sin código ni sintaxis", en resumen de un "lenguaje natural", es ante todo porque la selección que opera en el mundo visible es totalmente apropiada a su lógica, a la representación del mundo que se impuso en Europa desde el Quattrocento (BOURDIEU, 2003, p. 136).

En consecuencia, todo el proceso a través del cual una sección del mundo se convierte en fotografía es una convención y los códigos que regulan la imagen fotográfica están determinadas por sus usos sociales que - a excepción de la fotografía artística- establecen ciertas reglas que definen la corrección de la representación: nitidez, ángulo recto, amplia gama de tonalidades, claridad de los detalles, entre otros (RAURICH, 2009). En el siglo XIX la fotografía fue concebida para generar la ilusión de su equivalencia con la realidad y hoy, a pesar de los cambios tecnológicos, ese dispositivo continúa vigente.

Por lo tanto, lo que distingue la fotografía de otras imágenes no es la ausencia de códigos ni la iconicidad de la imagen, sino su indexicalidad. Es decir, no sólo se asemejan a lo retratado, sino que son huellas del referente y por tanto indicios de su existencia. Como señala Susan Sontag (2006, p. 19), una fotografía se constituye 
siempre como una prueba indiscutible de que sucedió algo determinado en esa representación fotográfica. "La imagen quizás distorsiona, pero siempre queda la suposición de que existe, o existió algo semejante a lo que está en la imagen".

En otro de sus textos, Barthes (2003) llama la atención sobre el hecho de que la fotografía está profundamente implicada en la construcción de la historia y la memoria. Para él, la fotografía previamente mirada, limitada, encuadrada y puesta en perspectiva por el fotógrafo que la recoge-, es testimonio de lo que ha existido y su único sentido es indicar, subrayar, mostrar su relación singular con una situación referencial determinada (punctum). La "fotografía jamás miente: o mejor, puede mentir sobre el sentido de la cosa, pero jamás podrá mentir sobre su existencia” (BARTHES, 2003, p. 134).

La fotografía como signo indexal geometriza, clasifica, archiva y, con ello, la imagen adquiere la posibilidad de participar en la legibilidad del mundo, pues, como señala Walter Benjamin (2005, p. 465), “el índice histórico de las imágenes no sólo dice a qué tiempo determinado pertenecen, dice sobre todo que sólo en un tiempo determinado alcanzan legibilidad". Georges Didi-Huberman (2015, p. 20) propone que las imágenes que logran trascender e instalarse como índice histórico son aquellas construcciones visuales que consiguen temporalizar singularidades en las que brota, "entre el inmenso archivo de textos, imágenes, o testimonios del pasado, un momento de legibilidad y memoria que aparece [...] como un punto crítico"; que hace posible una legibilidad del mundo a través de imágenes dialectilizadas; esto es, de imágenes que manifiestan relaciones, movimientos, intervalos, síntomas y contradicciones. De acuerdo con Didi-Huberman (2015), son imágenes que no sólo 
conjugan un tiempo histórico determinado al cual pertenecen y eventualmente pueden arrojar luz sobre el pasado; sino que al mismo tiempo exponen un régimen de historicidad, vale decir, manifiestan una suerte de relación social con el tiempo; y hacen de la imagen fotográfica un espacio simbólico en el que tiene lugar aquello que Walter Benjamin (2005, p. 465) llamó "dialéctica en reposo".

Como señala Sontag (2006), la fotografía es una manera de mirary no la mirada misma, pero es, a la vez, la manera ineludiblemente "moderna" de mirar. En una sociedad moderna donde las imágenes fotográficas fueron alguna vez mercancías de la realidad las imágenes realizadas por las cámaras están inextricablemente unidas con la realidad, pues no es sólo una interpretación de lo real; es también una traza, un negativo de lo real, como una huella o una máscara mortuoria que transforma a las personas en objetos que pueden ser poseídos simbólicamente. Una fotografía es una prueba irrefutable de existencia a la vez que, en nuestro mundo posmoderno, para que algo se convierta en real, debe haber imágenes. Dicho de otra manera, las imágenes fotográficas sincronizan nuestra mirada con el mundo, son muchas veces "nuestra mirada cambiante al mundo, y a veces también una mirada a nuestra propia mirada" (BELTING, 2010, p. 266).

La cámara fotográfica es entonces una herramienta a disposición de la memoria, del pasado y de la legibilidad del mundo, sin embargo, al respecto John Berger (1980) establece una distinción entre las imágenes públicas y las privadas. Las fotografías públicas, al tener contextos de producción y consumo completamente independientes, ofrecen a quien las observa información alejada de toda experiencia vivida. Por el otro lado, las fotografías privadas, 
producidas y consumidas dentro de un entorno de relaciones sociales cercanas, permanecen y adquieren significado dentro de ese mismo contexto. Esta distinción resultará de suma utilidad cuando más adelante nos refiramos a las fotografías producidas por los turistas, más aún si consideramos el hecho de que los motivos fotografiados se repiten una y otra vez, y básicamente son los mismos que encontramos en folletos, guías y postales.

\section{Patrimonio cultural, turismo masivo y alteridad}

Un primer acercamiento del término patrimonio cultural nos trae como evocación inmediata una relación de pertenencia y en algunos casos de herencia, sin embargo también puede ser entendido como una construcción sociocultural que se desarrolla a partir de un proceso en el cual participan una serie de instituciones y grupos de poder que dominan y controlan los intereses políticos y económicos. Así, por ejemplo, con el nacionalismo del siglo XIX se pusieron en marcha una serie de políticas destinadas a la reconstrucción de la identidad nacional, en base a la sanción de un conjunto de tradiciones y a la construcción de una memoria histórica compartida. Se comienza de esta manera a consolidar un proyecto integrador, sustentado en el Estado-nación, que elaboró imágenes, símbolos y patrimonios culturales que contribuyeron en la instauración de lo que lo Benedict Anderson (2006) ha denominado Comunidades imaginadas.

En la actualidad, la idea del patrimonio ha ido mutando y ya no se considera exclusivamente como un objeto destinado a la 
construcción de la identidad nacional o como un bien que hay que resguardar por derecho propio. Hoy en día el patrimonio se configura también como un bien de consumo, como un recurso económico en el campo del turismo, de la cultura del ocio y del entretenimiento. Como sostiene Josep Ballart (1997), desde el momento en que un individuo está dispuesto a pagar por ver algo, los bienes culturales se transforman en un objeto comercial cuya valoración es semejante a la de una visita a un centro recreativo. En los últimos sesenta años hemos asistido al estallido, desarrollo y consolidación de un mercado cultural en el que el patrimonio y su interpretación pueden actuar, no sólo como elemento generador de comunidades imaginadas, sino también participar en nuevas opciones de empleo e incidir en los agentes económicos de un determinado territorio, alimentado todo esto por una sociedad de consumo, donde la gran mayoría de las relaciones sociales se experimentan como representación.

Dentro del contexto del turismo la alteridad indígena se constituye como un valor cultural patrimonializable. Es decir, se resaltan aquellos aspectos que permiten construir la diferencia como exotismo cultural, y se privilegia destacar aquellos rasgos culturales que, una vez mercantilizados, se exhiben "para ser gozada solo por medio de la mirada" (AGAMBEN, 2006, p. 80). De esta manera, podemos pensar que mientras el indígena es cosificado bajo una forma que lo reduce a un valor de antigüedad premoderno y a un valor de uso intercambiable en el mercado de los bienes simbólicos del turismo y el patrimonio; configurando una alteridad monumentalizada, fetichizada como un bien de consumo destinado a prefigurar no sólo una imagen de lo indígena como sujeto ahistórico y despolitizado, sino también objetivado en "su actual valoración como ejemplares 
de una cuantificable diversidad cultural" (MENARD, 2016, p. 136). En consecuencia, el patrimonio cultural y el turismo se consolidan como un bien de consumo, que se objetiva como mercancía y se alimenta "sobre la categoría abstracta de una diferencia vuelta valor en sí. Así se hablará [...] de la diversidad cultural como patrimonio cuantificable" (MENARD, 2016, p. 134).

\section{Patrimonio, turismo e imagen: construcción de un destino}

El patrimonio es empleado para promover el turismo a una diversidad de destinos. Su objetivo principal es empaquetar una identidad para vender a los turistas; o, como señala Donald Horne (1984, p. 166), la identidad es "uno de los principios que colorean la visión turística".

La industria del turismo resalta ciertos temas que reaparecen constantemente y que se usan para simbolizar una nación, una identidad, un pueblo. Estos incluyen referencias al ambiente físico, específicamente el paisaje y la arquitectura, pero también a valores morales, como la sincronía con la naturaleza, etc. Todos estos elementos se constituyen como signos metonímicos y construyen el carácter de un país, el mito de un país. Y cuando hablamos de mito nos referimos al concepto bartheano del mito: un tipo de lenguaje, un tipo de discurso que sirve para representar aspectos de una cultura, "el mito no podría ser un objeto, un concepto o una idea; se trata de un modo de significación, de una forma" (BARTHES, 1999, p. 108). Es en el poder de estos mitos en los que se basa la industria 
del turismo para publicitar y vender destinos y atracciones, y en ese sentido se instala como un intermediario fundamental en la forma en que vemos el mundo, su diversidad y sus relaciones de poder.

La construcción de esos mitos supone la selección y difusión de ciertos aspectos como si ellos fueran "un fenómeno unificado representante de la nación" (WALSH, 1990, p. 178), divulgando una versión particular de lo local. En el caso de los países no occidentales, se privilegia lo exótico y lo extraño, para dramatizar el contraste entre visitantes y locales. En esta cometido la fotografía - difundida a través de guías, comerciales de televisión o postales -cumple un rol fundamental en la publicidad que convierte un lugar en un destino, en un producto de consumo. Al mismo tiempo, la práctica fotográfica está íntimamente relacionada con la actividad turística, con el ser un turista. Urry (2002) vincula estas fotografías de consumo público - que ofrecen a quien las observa información alejada de toda experiencia vivida- con las fotografías privadas - producidas y consumidas dentro de un entorno de relaciones sociales cercanas- sugiriendo que constituyen un circuito cerrado de representación que se refuerza a sí mismo, en el que las fotografías de los turistas reflejan y orientan las imágenes de los destinos.

Este vínculo nos recuerda lo afirmado por Gombrich (1979), quien plantea que la representación se construye a partir de la relación de las imágenes con otras imágenes. Esta afirmación apunta a dos vínculos que se complementan: por un lado, el vínculo entre la idea que se tiene de algo, la "imagen mental", como referencia de la imagen como cosa representada; a la vez que, para la concreción de esa imagen mental, se recurre a una serie de códigos preexistentes y reconocibles, un vocabulario de la semejanza, cuyo punto de partida 
son otras imágenes.

Las fotografías producidas por los turistas poseen este doble vínculo. Por un lado, se trata de capturar la imagen que se tiene de un lugar y la percepción que se tiene de esta esencia proviene de las fotografías ya conocidas y de amplia circulación que indican esquemas de percepción y de valoración que orientan y convierten los hechos desordenados en formas fácilmente reconocibles. Como señala Sontag (2006, p. 15), la fotografía nos proporciona un nuevo código visual, que alteran y amplían "nuestras nociones de lo que merece la pena mirar y de lo que tenemos derecho a observar. Son una gramática y, sobre todo, una ética de la visión".

En otras palabras, los monumentos, los paisajes o - sobre todo en el tercer mundo - las minorías étnicas, y por consiguientes sus representaciones fotográficas, actúan como signos que a través de una sinécdoque pasan a representar la totalidad del lugar. Como señala Jonathan Culler (1981, p. 128), el turista actúa como un semiólogo amateur "implicado en proyectos semióticos, leyendo ciudades, paisajes y culturas como sistemas de signos". Y esta lectura de signos no es secundaria al turismo, sino que es la forma y la razón central por la que éste tiene lugar.

\section{Perú y Bolivia, la esencia de lo andino}

Debido a la polisemia de la imagen, centrarse en el análisis de la fotografía siempre genera algún grado de inquietud. Es cierto que no podemos tener certeza acerca del propósito de quien hizo la fotografía ni de las múltiples interpretaciones de quienes las 
consumen, sin embargo en el caso de la fotografía turística no estamos hablando de imágenes aisladas. En los folletos y guías turísticas, las imágenes no sólo van acompañadas de textos, sino que junto a las postales forman parte de un conjunto cuidadosamente compuesto, seleccionado y publicado que actúa como narración sintética de un mismo referente - un país específico - y que tiene una función evidente: ilustrar y guiar una forma determinada de conocer y experimentar un lugar.

Si bien es posible asumir que en los últimos años la información disponible en internet ha asumido un rol cada vez más prominente en la búsqueda y selección de los destinos, las fuentes continúan siendo las tradicionales: organismos gubernamentales, agencias de turismo y editoriales especializadas. La mayor novedad la constituye la facilidad para acceder a los testimonios de otros viajeros. En ese sentido, resulta interesante contrastar las construcciones visuales difundidas por estos tres agentes - organismos oficiales, industria turística y turistas-, partiendo de la base de que no comparten exactamente los mismos objetivos. Si bien el turismo es una fuente de ingresos para cualquier país, cuando los gobiernos diseñan una imagen país no sólo buscan vender un destino sino hacer referencia a una identidad cultural que congregue a los nacionales y se presente como diferenciadora en el exterior. La industria turística, por su parte, busca identificar los intereses de los potenciales viajeros y ofrecer la satisfacción de esas expectativas en base a imágenes idealizadas. Las imágenes hechas y divulgadas por los turistas constituyen versiones individuales del lugar ya visitado y, por tanto, es de esperarse, son el producto de experiencias personales.

A pesar de lo anterior, al menos cuando limitamos nuestro 
material de análisis a la zona de Perú y Bolivia, llama la atención la similitud en el contenido de las imágenes generadas desde estos tres ámbitos. Sin querer profundizar en un análisis de la construcción de imagen país de estas dos naciones andinas, si parece necesario hacer un breve paréntesis para señalar que, durante el 2012, Perú inició una fuerte campaña de promoción que busca tanto atraer el turismo como las inversiones. De allí que en sus videos publicitarios se incluyan imágenes de emprendimiento empresarial, ausentes en el discurso divulgado por Bolivia. Sin ser este un dato menor, no podemos olvidar que el objetivo de este artículo es centrarnos en el vínculo entre patrimonio cultural y turismo, y en ese sentido las imágenes de las infraestructuras industriales aparecen desvinculadas del contexto sociocultural e incluso natural que el país ofrece. Desde esta perspectiva, la imagen proyectada por ambos países es casi idéntica y la distinción sólo es posible cuando se hace referencia a algún hito paisajístico reconocible.

Hecha esas acotaciones, y teniendo en mente la tesis central de este análisis - es decir, la reproducción de discursos colonialistas en la construcción del destino turístico-, presentamos primero un análisis de las imágenes divulgadas promocionalmente para luego referirnos a las fotografías producidas por los turistas.

Si hacemos referencia a los motivos representados ordenados en base a un criterio cuantitativo, es indudable que el nativo es el ícono que sobresale por la multiplicidad de imágenes que lo reproducen y por la prominencia que ocupa en las portadas de las guías (Figura 1). Siempre vestido en ropas exóticas, cuando no se trata de un retrato se lo muestra involucrado en actividades tradicionales, ya sea participando en fiestas y bailes rituales, 
manufacturando productos artesanales, cultivando la tierra con técnicas ancestrales o comercializando productos locales. Se trata de individuos monumentalizados y objetivados como hitos de una sociedad concebida como premoderna y en ello radica su exotismo y su valor turístico. La utilización de la imagen del indígena sobrepasa por mucho la representación del patrimonio arqueológico como esencia de lo peruano o lo boliviano (Figura 2). De este modo, el nativo es objetivado como un objeto de deseo, como un ícono al servicio de una ideología multicultural, en que la escenificación y exotización de la diferencia se configuran como una estrategia discursiva de poder, capaz de construir al "otro", porque el deseo de experimentar la diferencia es una de las motivaciones primarias de los turistas.

Figura 1 - Portada de la guía turística Hunter Travel Guides

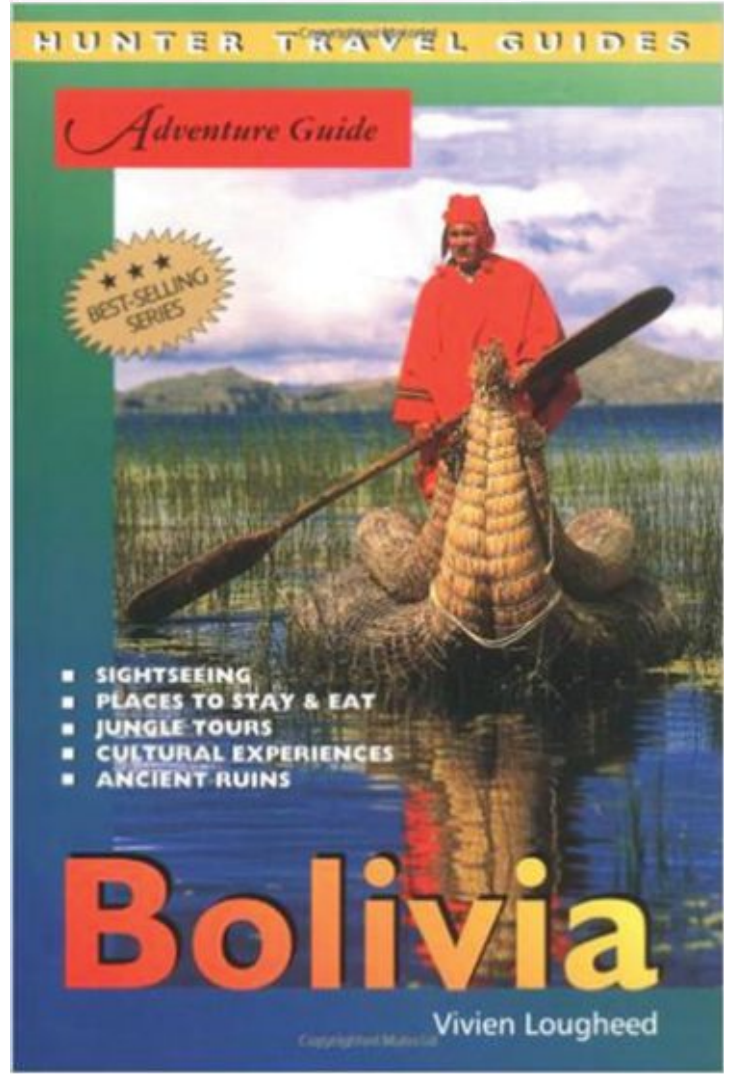

Fuente: Hunter Travel Guides 
Figura 2 - Portada guía turística Bradt

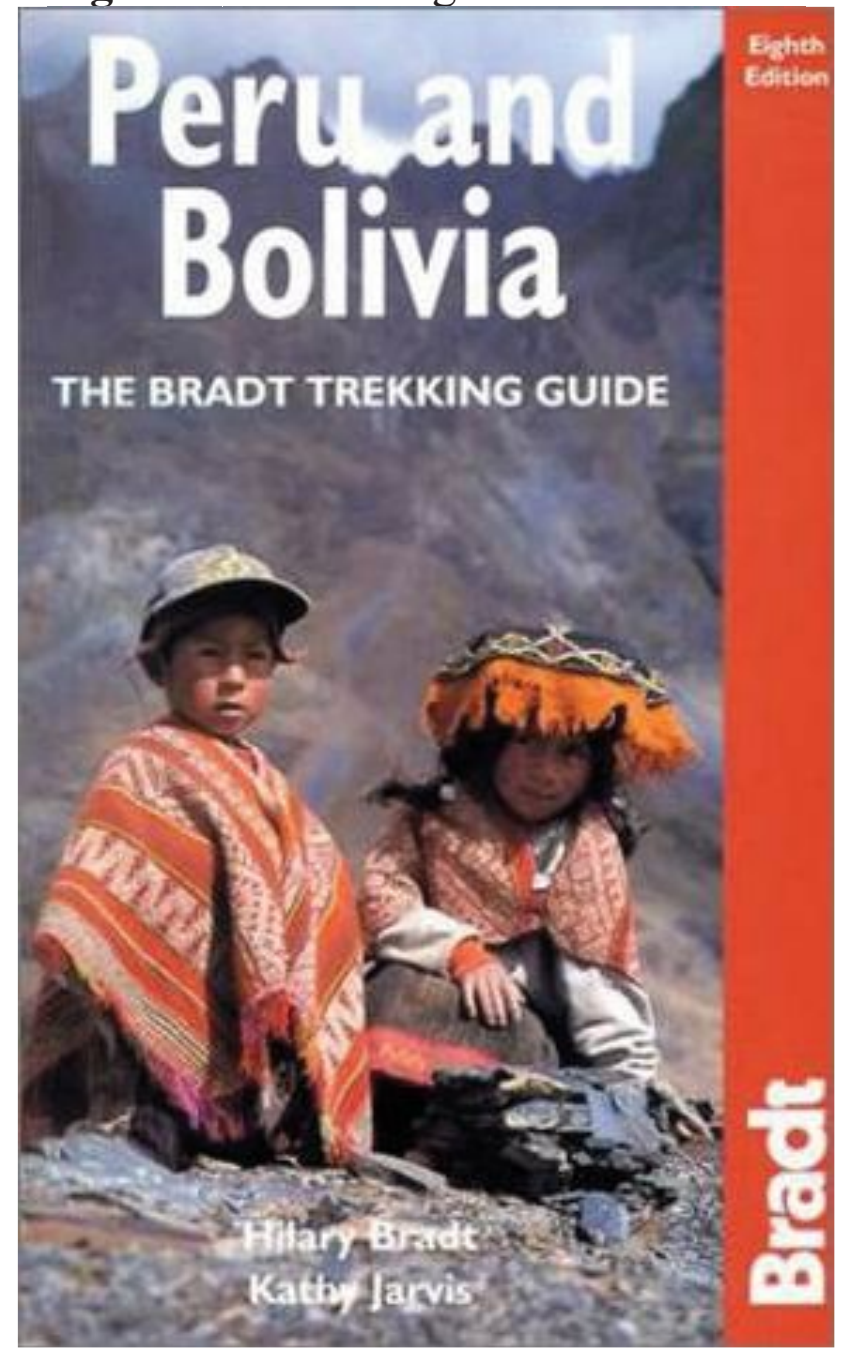

Fuente: Bradt

Las agencias gubernamentales, por su parte, si bien de ningún modo prescinden del ícono indígena, parecieran querer girar el foco de atención hacia el visitante. Ambos países destacan y de algún modo guían el comportamiento ideal de los turistas, que son representados disfrutando o consumiendo servicios: deleitándose de las comodidades de sus alojamientos, practicando deportes náuticos, explorando paisajes naturales o visitando el patrimonio material equipados con cámaras o posando frente a los monumentos arqueológicos. Al turista nunca se lo retrata en un entorno urbano y si se lo presenta interactuando con los locales, es porque es el receptor de un servicio (Figura 3). 
Figura 3 - Portal de Turismo

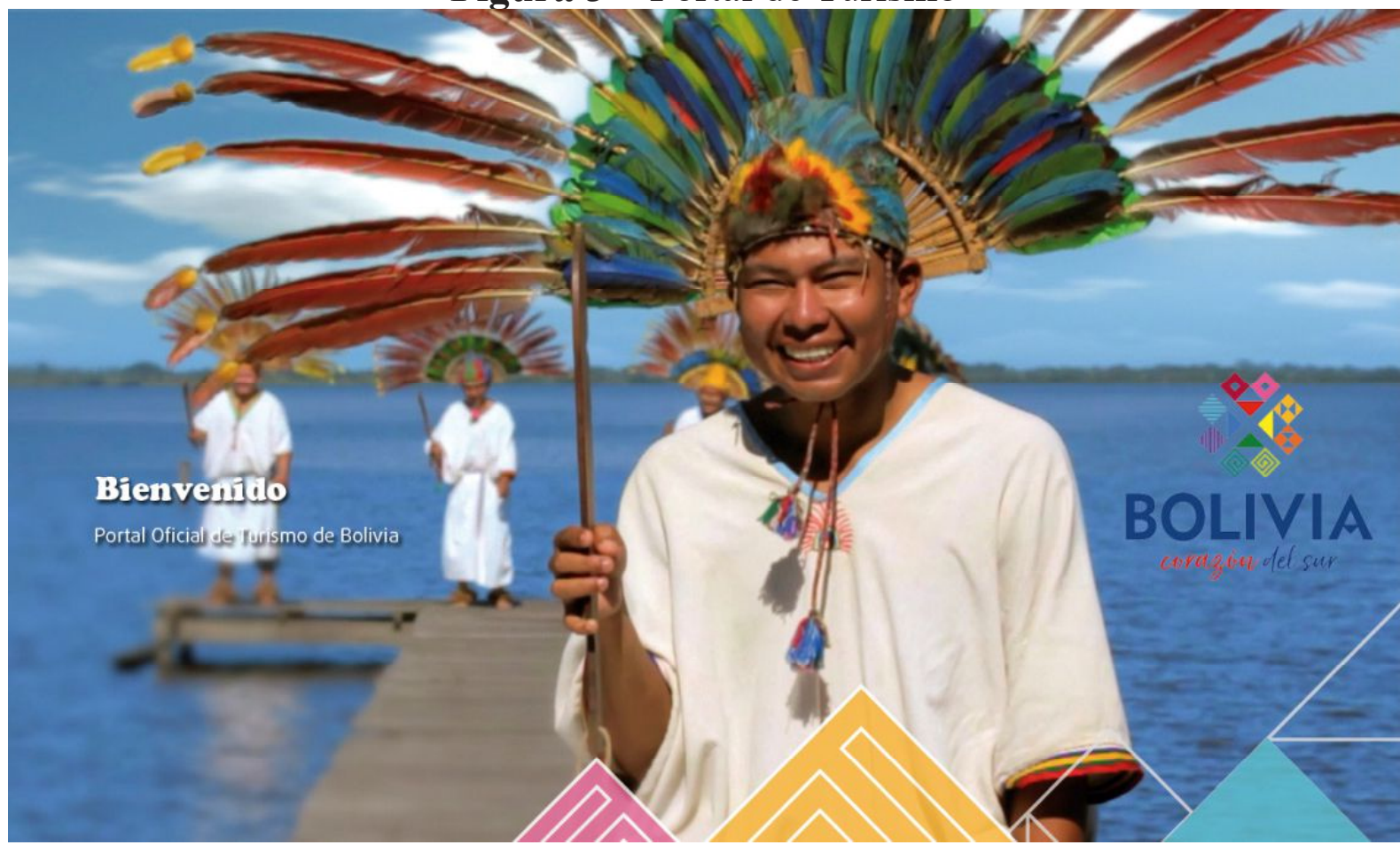

Fuente: $\underline{\text { http://turismo.minculturas.gob.bo/ }}$

En términos de escenarios, los paisajes naturales prístinos representados por montañas, lagunas, playas o selvas sin huellas de presencia humana, aparecen mucho más frecuentemente que los escenarios con patrimonio arqueológico. En tanto las ciudades sólo son presentadas en base a algunos hitos arquitectónicos y no existen referencias a los paisajes cultivados, domesticados.

Todas estas imágenes están orientadas a un potencial turista e indudablemente alientan una interpretación ideológica del destino que se le propone. En otras palabras, el atractivo que potencialmente convierte un lugar en destino no descansa en las cualidades de la imagen o en el referente específico que representa, sino en los mitos que el conjunto de estas imágenes construye (Figura 4).

Por sobre todo, y recurriendo a la imagen del nativo, se elabora el mito de lo inmutable. Aislado o periférico al mundo 
contemporáneo, el indígena andino sonriente aparece como una reliquia que supuestamente aún vive como lo hacían sus antepasados (Figura 5). Al turista se le ofrece un vistazo a un mundo exótico y anacrónico por elección, libre de cuestionamientos incómodos acerca de las relaciones asimétricas que han caracterizado la historia de estas etnias con los poderes occidentales y que ahora se perpetúan a través del turismo. Esta percepción se ve reforzada por las imágenes de una naturaleza virgen que refieren al mito de lo no domesticado, de lo salvaje. Paisajes aparentemente nunca tocados por el pie humano, que esperan ser descubiertos y explorados por los turistas. En definitiva, estos mitos refuerzan una construcción binaria que estructura el mundo entre moderno/antiguo, avanzado/ decadente, autosuficiente/dependiente de otros para progresar.

Figura 4 - Portal de Turismo

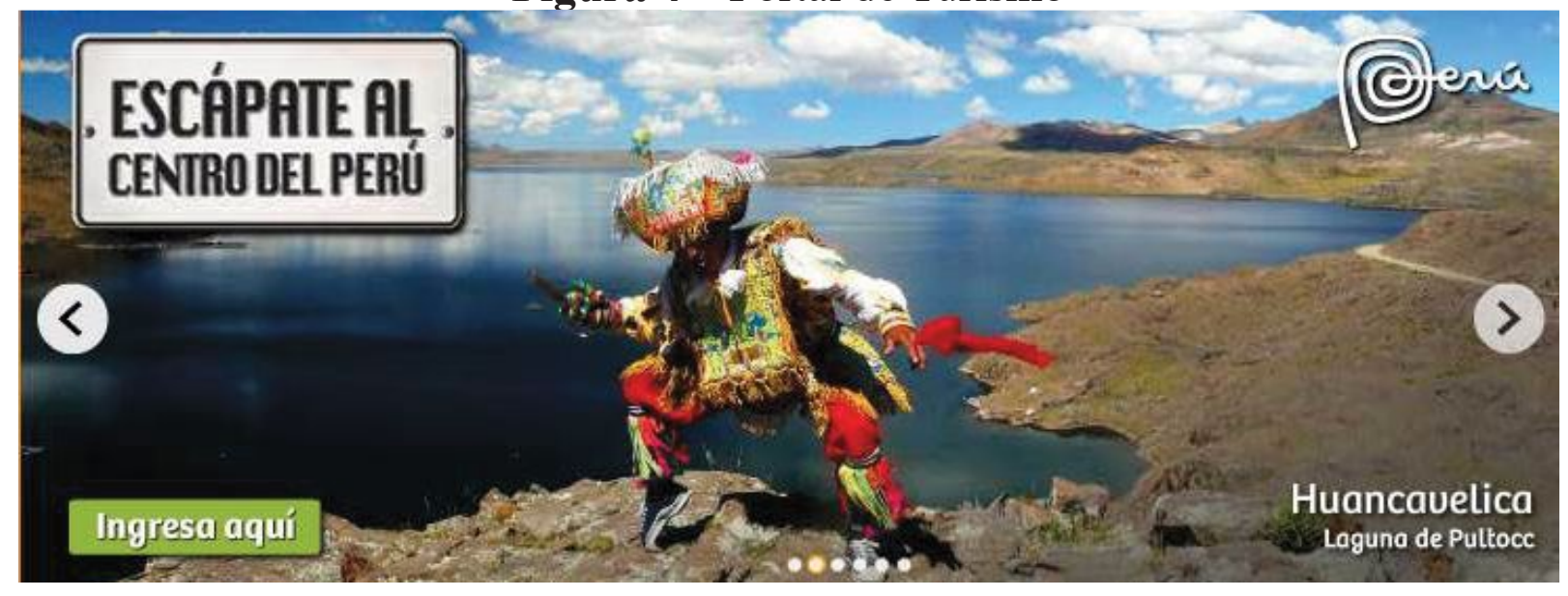

Fuente: https://www.gob.pe/mincetur 
Figura 5 - Portal de Turismo

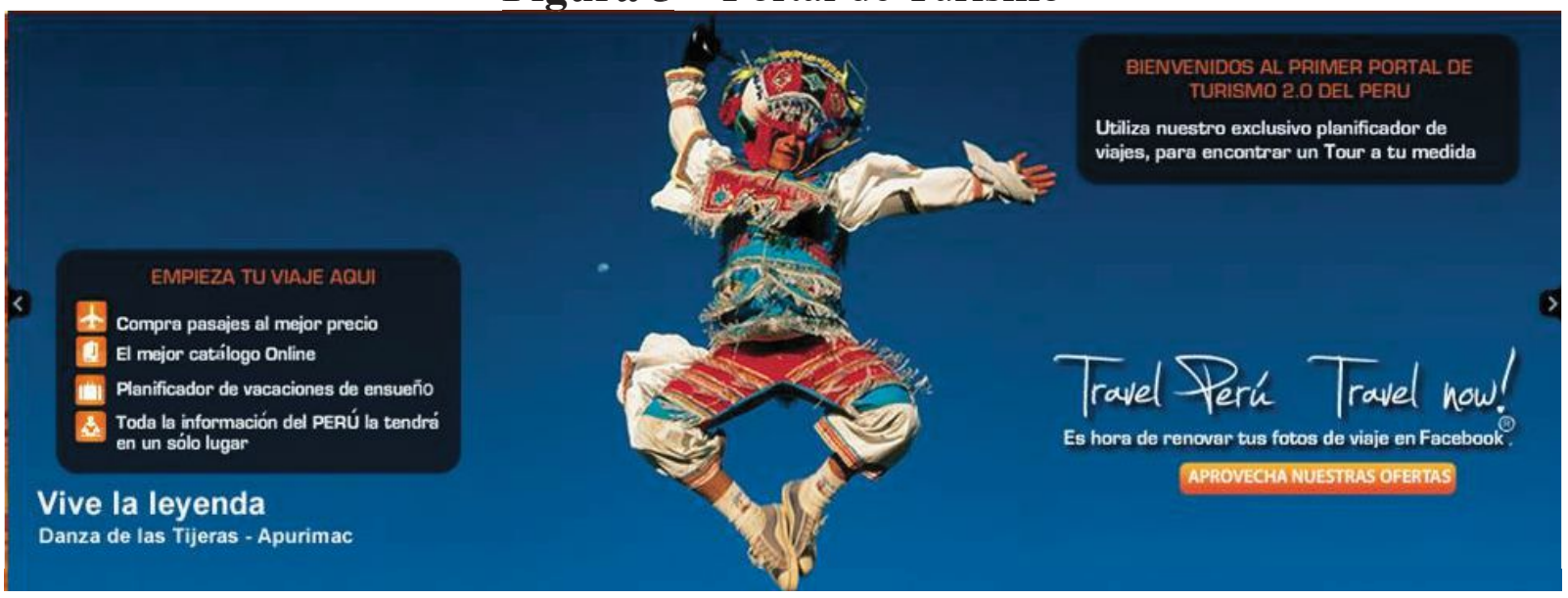

Fuente: https://www.peru.travel/es-lat/

En ese sentido, el turismo forma parte de un marco discursivo más amplio en el que se inscriben relaciones de poder y dominio, que se manifiestan y reproducen a través de textos turísticos como la fotografía. La pregunta entonces es hasta qué punto este discurso es recogido y reproducido por el viajero que efectivamente selecciona estos destinos y se enfrenta a la realidad de los lugares.

La revisión de las imágenes producidas por los turistas revela que en buena medida estas reiteran los motivos y escenarios descritos anteriormente: indígenas en vestimentas tradicionales posando o inmersos en actividades tradicionales, amplios paisajes no intervenidos, hitos arqueológicos y arquitectónicos. Dentro de esta numerosa reiteración resaltan contadas excepciones que por su rareza son reveladoras de lo que las agencias silencian por razones obvias y que los turistas deciden omitir de sus recuerdos del viaje. En primer lugar, son pocas las imágenes en las que se muestra interacción entre locales y turistas y en esas pocas instantáneas se presentan dos situaciones: el turista es retratado rodeado de nativos sonrientes - preferentemente niños- o el nativo está prestando un 
servicio al turista -remando un bote, lustrando zapatos, haciendo de guía (Figura 6 y 7). En general las ciudades son fotografiadas en planos generales que no dan más que una imagen del conjunto, sin embargo las pocas veces que esta regla se rompe es para resaltar la precariedad de la vida urbana. Pero esas imágenes son anomalías. La mayoría de los turistas regresan a su lugar de origen para reiterar un relato en el que todo es fotogénico, no hay pobreza sino tradición, no hay relaciones de poder sino nativos acogedores.

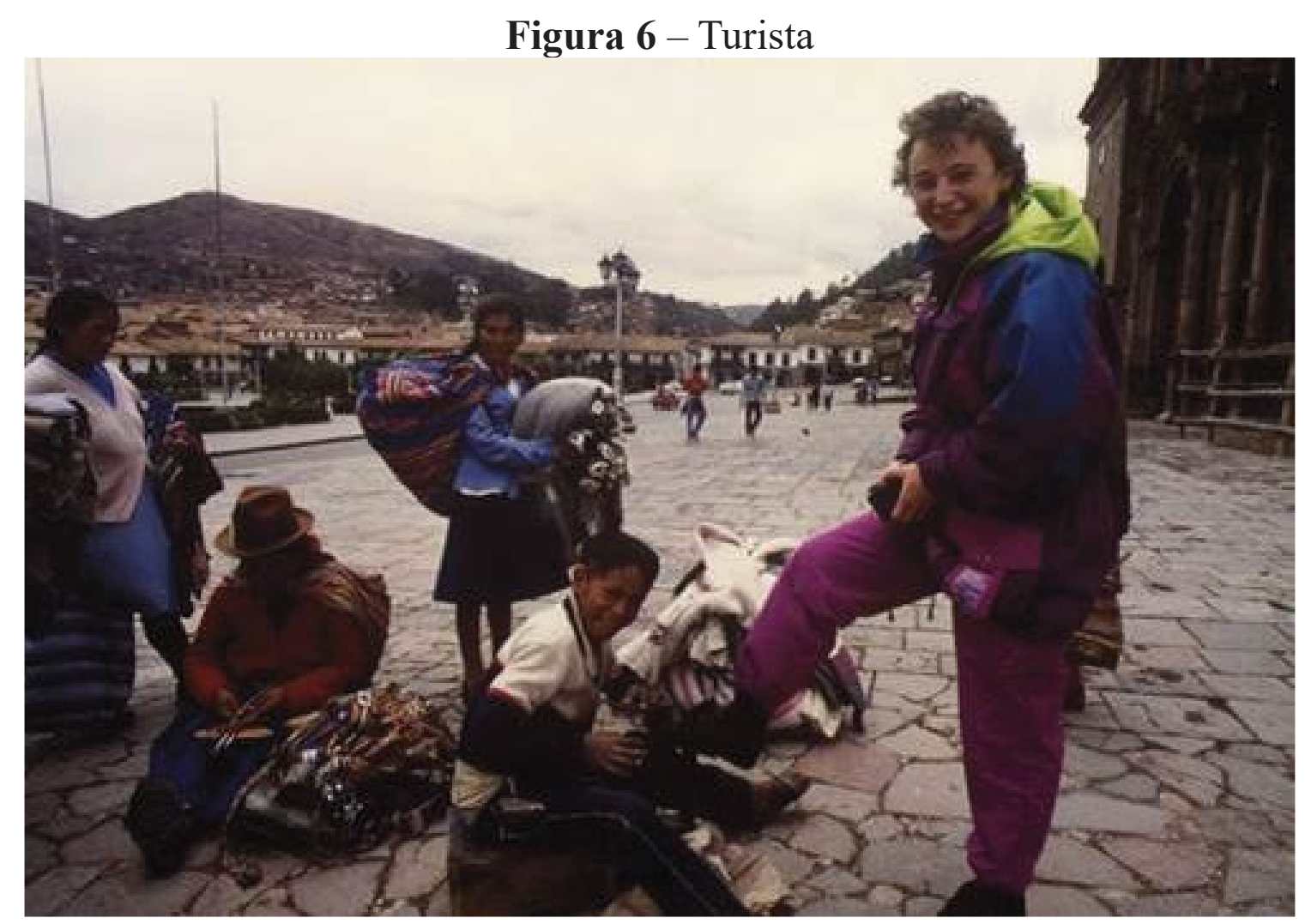

Fuente: https://www.viajeros.com 
Figura 7 - Turista

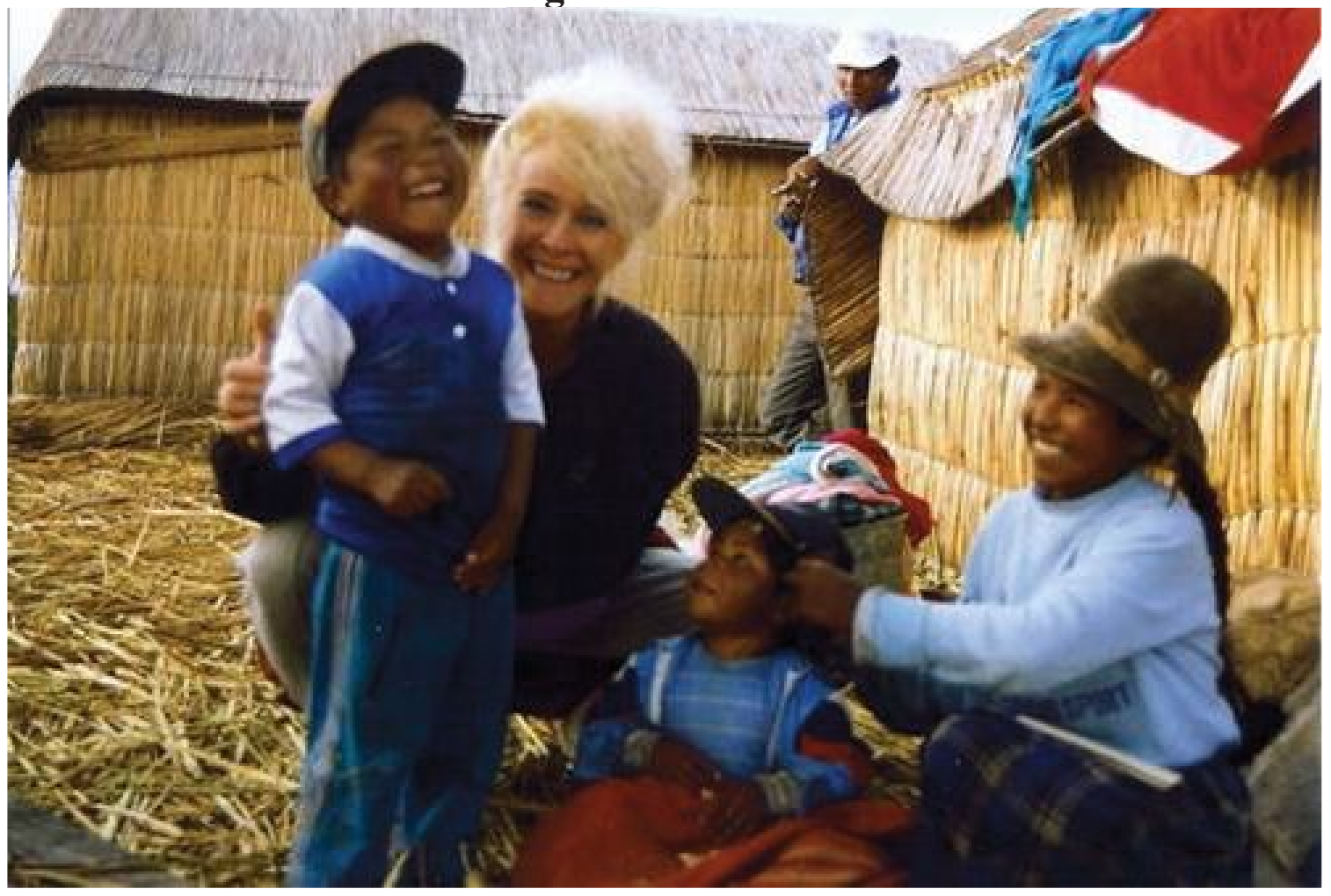

Fuente: https://www.viajeros.com

En este sentido, "la comercialización del encuentro turístico se extiende al punto de mercantilizar no sólo las artesanías y la imagen fotográfica sino la persona del exprimitivo". (MACCANNELL, 2007, p. 38) Por lo tanto, la mercantilización que el turismo y el turista hace del nativo, de su medio ambiente y de su estilo de vida, no es más que una de las múltiples caras que adopta, hoy en día, las asimétricas relaciones de poder que se establecen dentro de la lógica del capitalismo tardío. Por otro lado, el turismo se configura como un espectáculo (en el sentido que Debord le da a este término), donde a veces no son tan llamativos los extravagantes efectos que tienen los desmesurados "intentos de los turistas por adoptar las costumbres de los nativos como los intentos de los nativos por satisfacer las expectativas de los turistas o, por decirlo de otra 
manera, por adoptar sus propias costumbres expresamente para los turistas". (MACCANNELL, 2007, p. 166). Uno de los resultados tangibles de esto es la fetichización de alteridad que, positivada en las representaciones de la fotografía turística y de la práctica del turismo, dejan entrever un cierto enaltecimiento y reivindicación del exotismo como autenticidad cultural, reduciendo lo indígena a una a una serie de imágenes e imaginarios que los despojan la posibilidad de una inscripción social y política concreta, que se desvanece en su exótica diferencia devenida como singularidad histórica de su valor de uso y de cambio.

\section{Conclusiones}

Como hemos visto a lo largo de este trabajo, la relación entre turismo, patrimonio y fotografía nos remiten hacia una dialéctica de lo simbólico en la cual, la imagen y el relato que construye el turismo y el turista sobre una determinada comunidad o parte de ella, dejan entrever un habitus que es eminentemente dinámico y, tal como señala Pierre Bourdieu (2008), se encuentra integrado dentro del campo del turismo y se constituye en una "estructura y estructurante" -puesto que organiza las prácticas ligadas al turismo y el modo en que son interpretadas bajo la lógica del patrimonio y la fotografía, como en una "estructura estructurada"- que emerge de las condiciones objetivas que no pueden ser eludidas dentro contexto social del capitalismo de consumo. De este modo, los habitus del turista y el campo del turismo absorbe y cosifica el patrimonio y prácticas culturales como bienes de consumo masivo que, representado bajo 
la legibilidad de la práctica fotográfica, dejan entrever el modo en que los turistas participan en los procesos de producción de sentido y significación que hacen de los lugares turísticos un espacio social signado de acuerdo a los variables posicionamientos que ocupan los nativos según su clase, raza, género, etc. (MORAÑA, 2014). Por lo tanto, las representaciones fotográficas de la alteridad dentro del contexto del turismo masivo, al estar insertas dentro de la red de sistemas simbólicos, se constituyen como herramientas no solo de conocimiento y construcción del mundo objetivo, sino también de legitimación y dominación de una clase sobre otra (BOURDIEU, 2006).

Esta construcción del mundo que hace la industria de turismo (apoyada, incentivada y muchas veces pauteada de acuerdo con agencias gubernamentales) posee un riesgo particular. A diferencia de la publicidad de productos en general, cuya función principal es generar falsas necesidades o convencernos de que sus productos van más allá que sólo satisfacer carencias materiales, el turismo no sólo convierte a los pueblos y sus patrimonios en productos de consumo, sino que modela la percepción del mundo y su diversidad. No se trata sólo de la imagen estereotipada que se proyecta, sino de cómo las categorías pueden ser internalizadas hasta el punto en que el turista que visita el lugar no sólo retrata precisamente aquello que de antemano ha calificado como representativo sino que, en ocasiones, a pesar de haberse enfrentado a las complejidades del contexto histórico, cultural, político y económico del atractivo turístico, retorna a su cotidianeidad y reproduce sin reservas, pero en primera persona, el mito aprendido.

En consecuencia, los turistas no solo son consumidores 
pasivos de la industria del turismo, de los clichés y las imágenes que adornan la experiencia turística, son también sujetos activos y creativos que se apropian de esos discursos públicos y los transforman en versiones personales destinadas a ser compartidas con su entorno social (RAURICH, 2009). En tal sentido, el turismo cultural no es un fenómeno limitado en el tiempo y en el espacio al momento de la visita turística. El turismo no es solo un conjunto de actividades comerciales; también es un marco ideológico, un espacio de poder capaz de moldear la cultura y los imaginarios de acuerdo a sus propias necesidades e intereses (DESMOND, 1999). De ahí que sea un fenómeno que afecte exclusivamente a los países no occidentales -los países del viejo continente son objeto de una simplificación similar, anclados para siempre en las glorias de una antigüedad idealizada- sin embargo, cuando no se dispone de una industria cultural capaz de difundir otras versiones, la frecuencia y la alta visibilidad de estas imágenes seleccionadas por agencias gubernamentales o agentes turísticos invisibilizan las construcciones alternativas u opuestas.

En definitiva, el riesgo del turismo es que este deviene en un simulacro del viaje y del encuentro, en el que se disfruta la ilusión de estaren ellugarmientras los atractivos y percepciones predeterminadas obscurecen el contacto con la realidad o simplemente la borran. Dentro de este contexto, las imágenes fotográficas que emergen de la práctica del tursimo se convierten "en lugares carentes de lugar. Después que los lugares se han perdido en el mundo, se refugian en imágenes que les pueden otorgar nuevamente un estatus alternativo como lugar" (BELTING, 2010, p. 77-78). Se trata, de algún modo, del Crimen perfecto pronosticado por Baudrillard (2009), que en el 
juego de los simulacros y las simulaciones se pone en tela de juicio la diferencia entre lo verdadero y lo falso, entre lo real y lo imaginario, entre el fetiche culturalista y la mercantilización de la otredad.

\section{Referencias}

AGAMBEN, Giorgio. Estancias: la palabra y el fantasma en la cultura occidental. Valencia: Pre-Textos, 2006.

ANDERSON, Benedict. Comunidades imaginadas: reflexiones sobre el origen y la difusión del nacionalismo. México, DF: Fondo de Cultura Económica, 2006.

BALLART, Josep. El patrimonio histórico y arqueológico: valor y uso. Barcelona: Ariel, 1997.

BARTHES, Roland. El mensaje fotográfico: lo obvio y lo obtuso: imágenes, gestos, voces. Barcelona: Paidós, 1986.

BARTHES, Roland. La cámara lúcida: nota sobre la fotografía. Buenos Aires: Paidós, 2003.

BARTHES, Roland. Mitologías. México, DF: Siglo XX Editores, 1999.

BAUDRILLARD, Jean. El crimen perfecto. Barcelona: Anagrama, 2009.

BELTING, Hans. Antropología de la imagen. Madrid: Katz Editores, 2010.

BENJAMIN, Walter. El libro de los pasajes. Madrid: Akal, 2005.

BERGER, John. About looking. Nueva York: Pantheon Books, 1980. 
200 El gusto por los otros: turismo, fotografía y patrimonio cultural en el contexto andino

BLANCHOT, Maurice. Michel Foucault tal como yo lo imagino. Valencia: Pre-textos, 1993.

BOURDIEU, Pierre. Cuestiones de sociología. Madrid: Akal, 2008.

BOURDIEU, Pierre. Sobre el poder simbólico: intelectuales, política y poder. Buenos Aires: EUDEBA, 2006.

BOURDIEU, Pierre. Un arte medio. Barcelona: Editorial Gustavo Gili, 2003.

CHANG, Him-Ching; HOLT, Richard. Tourism as consciousness of struggle: cultural representations of Taiwan. Critical Studies in Mass Communication, Annandale, v. 8, p. 102-118, 1991.

CULLER, John. Semiotics of tourism. The American Journal of Semiotics, Charlottesville, v. 1, n. 1, p. 127-140, 1981.

DESMOND, Jane. Staging tourism: bodies on display from waikiki to sea world. Chicago: University of Chicago Press, 1999.

DIDI-HUBERMAN, Georges. Remontajes al tiempo padecido: el ojo de la historia 2. Buenos Aires: Editorial Biblos, 2015.

ECHTNER, Charlotte; PRASAD Pushkala. The context of third world tourism marketing. Annals of Tourism Research, New York, v. 30, n. 3, p. 660-682, 2003.

FLUSSER, Vilém. Hacia una filosofía de la fotografía. México, DF: Editorial Trillas, 1990.

GARCÍA CANCLINI, Néstor. Diferentes, desiguales y desconectados: mapas de la interculturalidad. Barcelona: Gedisa, 2005.

GOMBRICH, Ernest. H. Arte e ilusión: estudio sobre la psicología de la representación pictórica. Barcelona: Editorial Gustavo Gili, 1979. 
HORNE, Donald. The great museum: the re-presentation of history. London: Pluto Press, 1984.

MACCANNELL, Denis. Lugares de encuentro vacíos. Barcelona: Melusina, 2007.

MENARD, André. El devenir imagen del indígena. Diálogo Andino, Casilla, n. 50, p. 133-140, 2016.

MORAÑA, Mabel. Bourdieu en la periferia: capital simbólico y campo cultural en América Latina. Santiago de Chile: Editorial Cuarto Propio, 2014.

QUIJANO, Anibal. Colonialidad del poder y clasificación social. In: CASTRO-GÓMEZ, Santiago; GROSFOGUEL, Ramón (ed.). EI giro decolonial: reflexiones para una diversidad epistémica más allá del capitalismo global. Bogotá: Siglo del Hombre Editores, 2007. p. 93-126.

QUIJANO, Anibal. Colonialidad y modernidad/racionalidad. Perú Indígena, Lima, v. 13, n. 29, p. 11-20, 1992.

RAURICH, Valentina. Lugares comunes: fotografía y turismo. Ankulegi Aldizkaria: Revista de Antropología Social, San Sebastián, n. 13, p. 33-43, 2009.

SAID, Edward. Cultura e imperialismo. Barcelona: Anagrama, 2001.

SONTAG, Susan. Sobre la fotografía. México, DF: Alfaguara, 2006.

URRY, John. The tourist gaze. London: Sage, 2002.

WALLERSTEIN, Inmanuel. The modern world system. New York: Academic Press, 1989. 
202 El gusto por los otros: turismo, fotografía y patrimonio cultural en el contexto andino

WALSH, Kevin. The representation of the past: museums and heritage in the post-modern world. London: Routledge, 1990. 